\title{
TRANSNATIONAL YOUTH AND THE ROLE OF SOCIAL AND SOCIOCULTURAL REMITTANCES IN IDENTITY CONSTRUCTION
}

\section{JUVENTUDE TRANSNACIONAL E O PAPEL DAS REMESSAS SOCIAIS E SOCIOCULTURAIS NA CONSTRUÇÃO DE IDENTIDADE}

\section{Alejandra Núñez Asomoza*}

\begin{abstract}
Within a framework of transnationalism, and through narrative analysis using the Labovian model, this paper offers a discussion of the role of social and sociocultural remittances in the identity construction of transnational youth pursuing tertiary education in a public university in central-north Mexico. Through the exploration of oral data from semistructured interviews the discussion aims at providing evidence of the ties and engagement that the participants develop on both sides of the Mexico-U.S. border through the exchange of goods, values, worldviews, attitudes, practices and linguistic elements, and how these impact their personal identity construction. The data presented in this paper come from a portion of qualitative corpora of a study in progress conducted by the author as a Ph.D project at Trinity College Dublin.
\end{abstract}

Keywords: transnational youth; socio-cultural remittances; identity.

\section{RESUMO}

Dentro de um quadro de transnacionalismo e através da análise narrativa usando o modelo de Labovian, este artigo oferece uma discussão sobre o papel das remessas sociais e socioculturais na construção da identidade dos jovens transnacionais à procura de educação terciária em uma universidade pública no centro-norte do México. Através da exploração de dados orais decorrentes de entrevistas semiestruturadas, a discussão visa fornecer evidências dos laços e do engajamento que os participantes desenvolvem em ambos os lados da fronteira México-EUA através da troca de bens, valores, cosmovisões, atitudes, práticas e elementos linguísticos, e como estes influenciam a construção de sua identidade pessoal. Os dados apresentados neste artigo vêm de uma seção de corpora qualitativos de um estudo em andamento conduzido pelo autor como um projeto de doutorado no Trinity College de Dublim.

Palavras-chave: juventude transnacional; remessas socioculturais; identidade.

\footnotetext{
* Trinity College Dublin, Irlanda. nuezasoa@tcd.ie

The author wishes to acknowledge the Mexican National Council of Science and Technology (CONACYT) and the Autonomous University of Zacatecas "Francisco García Salinas" for granting the funding and support to contuct her Ph.D study.
} 


\section{INTRODUCTION}

Population mobility goes beyond the simple idea of being transplanted from one place into another. It is a complex phenomenon, one so intricate that is even described by Castles, De Haas \& Miller (2014) as "one of the most important factors of global change" (p.7). The magnitude of the phenomenon is portrayed in the number of global immigrants recently calculated in over 258 million (UNITED NATIONS, 2017), the same immigrants who were responsible for sending approximately 600 billion (USD) economic remittances to their countries of origin throughout 2016 and 2017 (PEW RESEARCH CENTER, 2018; YMRM, 2017). Through those remittances they contribute to alleviate their individual economic needs and those of their families left behind, which are in most cases one of the main reasons that motivate people to engage in border crossing (MASSEY ET AL., 2010).

The movement of people across borders activates a massive exchange of remittances, which have been classified by scholars into different groups and types according to particular features that shall be discussed later in this paper. In broad terms, scholars investigating the phenomenon of migration and transnationalism have identified particular types of remittances other than economic, such as: social remittances aimed at sharing information of what is learned in the process of (im)migration (LEVITT, 1998), and sociocultural remittances mostly embodied in "symbolic goods" (MARTÍNEZ-GÓMEZ \& LLO-TEPOX, 2017, p.324; RIVERASÁNCHEZ, 2004, p.62), which among other effects aim at alleviating the affective loss caused by the act of (im)migrating. On the one hand, the exchange of social remittances comes as part of the migration journeys through which individuals carry with them what can be described as a baggage that is made up of elements such as values, ideas, behaviors, literacies and practices taken from the environments accessible to them virtually and physically as a result of globalization (APPADURAI, 1996). In most cases such elements are shared with the non-mobile population who also receives the influence of global synergies without leaving their place of residence, and these are reinforced or validated through the experience of migration. On the other hand, sociocultural remittances can be associated to the complementary remittances of Durand (2007) or to what Boruchoff (1999) coined as cultural baggage made up of a series of objects and materials that are exchanged in an effort to strengthen the affective ties spanning across the border. This complex dynamic where myriad elements converge and flow in people's worlds and spaces leads them to find new ways to interact and exchange elements of their sets of baggage, 
thus leading to fluid and alternative ways to construct their identity and sense of belonging.

Suspended in the journeys of their family's border crossing practices are the children and youths of (im)migrants, who in many cases become active participants, recipients and/or vehicles for the transmission of social and sociocultural remittances as a result of the transnational practices, processes and profiles that constitute the emergence of the transnational social fields they inhabit (FOURON \& GLICK-SCHILLER, 2002; LEVITT \& LAMBA-NIEVES, 2011). Understanding how these types of remittances are exchanged and perceived by transnational youths' is imperative considering that previous studies have found the positive effects that connections to the family's country of origin have in the process of identity construction and sense of belonging (SMITH, CITED IN BORUCHOFF, 2010). It is important to consider here the fact that the historic and unceasing migration flow between Mexico and the United States has been described as "one of the largest mass migrations in modern history" (PEW RESEARCH CENTER, 2011, P.8). Therefore, this paper looks at some types and examples of social and sociocultural remittances revealed in the narratives of transnational youth pursuing tertiary education in central-north Mexico to account for the emergence and subsistence of 'unique forms' of transnationalism in their lives across the specific case of the Mexico-U.S. border.

\section{TRANSNATIONAL YOUTH}

Within the context of transnationalism understood as a process of purposeful development of cross-border connections among mobile individuals or populations (VICKERMAN, 2002), the offspring of transnational families develop "significant ties to two or more nation-states"(SKERRET, 2015, p.2). Martínez Gómez \& Tlelo Tepox (2017) define transnational families in terms of the ties and "commitments sustained with family members across borders" (p.327). This notion of family ties and connectedness across borders is precisely what distinguishes transnational youtbs from immigrant children or youths who are strongly rooted to a country of settlement (ZÚÑ̃IGA \& HAMANN, 2009; SKERRET, 2015). According to Zúñiga \& Hamann (2009) the unique journey experienced by transnational youths impacts directly on their identity construction, as it constantly offers scenarios for the negotiation of myriad of social and cultural aspects of their lives and activities. Derived from their migration journey, transnational youths develop specific profiles, skills and roles embedded in the dynamics of being part of a transnational family's nucleus that is 
constantly receiving input on the values and ideologies found on the path of migration and nourished by means of "affective links" (MOCTEZUMA, 2017, p. 37) across the distance. Consequently, transnational youths find themselves swinging between at least two cultural frameworks of reference that are continuously negotiated.

Skerret (2015) reports that recent research calculates there are "several million" transnational children around the world, however "there are no official statistics on the numbers of transnational families and youths in nations such as the United States" (pp.2-3). Regarding the situation in Mexico, there have been recent significant efforts to begin to quantify and document the experiences of transnational and returnee children enrolled in basic education (e.g. AVILÉS \& MORA PABLO, 2014; BORJIAN, MUÑOZ DE COTE, VAN DIJK \& HOUDE, 2016; E. HAMANN \& VICTOR ZÚÑNIGA, 2011; E.T. HAMANN \& V. ZÚÑNIGA 2011; HAMANN, ZÚÑIGA \& SÁCHEZ GARCÍA, 2008). Additionally, there is a growing body of research focused on illuminating the process of the professional identity construction of transnational English teachers in Central Mexico (CHRISTIANSEN, TREJO GUZMÁN \& MORA PABLO, 2018; MORA PABLO, RIVAS RIVAS, LENGELING \& CRAWFORD, 2015; SERNA-GUTIÉRREZ \& MORA PABLO, 2017). Although the research conducted so far has shed light on the issues faced by these specific groups of transnational youths, more work remains to be done in order to amplify our knowledge on how these youths engage in transnational practices through the exchange of social and sociocultural remittances (DURAND, 2007; MARTÍNEZ GÓMEZ \& TLELO TEPOX, 2017).

\section{SOCIAL AND SOCIOCULTURAL REMITTANCES}

As stated previously, additionally to the vast and growing exchange of monetary remittances characteristic of international migration movements (LEVITT \& LAMBA-NIEVES, 2011; VERTOVEC, 2009), (im)migrants are active partakers in the exchange of other types of remittances. Durand (2007) expanded his proposal of a typology of remittances made in the early 90 s to a total of three main groups, with three types of remittances each: 1) Basic remittances, including salary, investment and capital. These remittances allow migrants and their families to cover the basic living expenses related to clothing, food, housing and selfemployment, 2) Complementary remittances, comprising in-kind, social and systemic. This group of remittances has a symbolic element, as they go to support education, health, associations or social programs that benefit the communities where migrants and their families are involved. 3) Additional remittances, encompassing dissipation, 
prestige and technology. This last group is concerned with the money 'losses' inherent to transfer fees or extortions, the monetary support for family celebrations and finally, the knowledge acquired by migrants while abroad. Groups 2 and 3 in Durand's typology highlight remittances that have a social component rather than a purely economic or quantitative value. A later classification of remittances comes from Levitt (1998), who defined social remittances specifically as "the ideas, behaviors, identities, and social capital that flow from receiving to sending-country communities"(p.927). Levitt categorized social remittances into three groups comprising: 1) Normative structures, including "ideas, values and beliefs", 2) Systems of practice, containing "the actions shaped by normative structures" (practices carried out by individuals or organizations in given domains), and 3) Social capital, referring to the 'power' gained from the "prestige and status" of living abroad (LEVITT, 1998, p.933-935).

The notion of non-economic remittances has also been captured by the concept of sociocultural remittances, which are rather understood as the "symbolic goods" or objects that physically circulate from one side of the border to the other with the purpose of "expressing affection"(MARTÍNEZ-GÓMEZ \& TLELO-TEPOX, 2017, p.323-324) and "reconstructing the sense of community" at the time that they "recreate" the identities of the mobile and non-mobile (RIVERA-SÁNCHEZ, 2004, p.73). In a recent revision of their conceptualization, Levitt and Lamba-Nieves (2011) recognize that social remittances can be transferred both individually and collectively, consequently playing significant roles at the micro and macro levels. Therefore, they argue that the analysis of "how social remittances travel" (p.3) must be observed within a framework of transnationalism in which "the possibility of migration takes place within a transnational social field"(p.3). In other words, traces of social remittances understood as ideological transfers, in addition to sociocultural remittances aimed specifically at strengthening affection and community building, would emerge from the exploration of the channels connecting mobile and non-mobile actors across borders (LEVITT \& GLICK-SCHILLER, 2004).

\section{THE STUDY AND CONTEXT: TRANSNATIONAL STUDENTS IN A 'BINATIONAL' STATE}

This paper draws on a portion of qualitative data taken from a $\mathrm{Ph} . \mathrm{D}$ study currently in progress ${ }^{1}$, which investigates the language practices of a group of

1. Dr. Sarah O’Brien from Trinity College Dublin supervises the research in progress. 
transnational students enrolled in tertiary education in central-north Mexico and their impact in their identity construction. The study in progress involves the participation of students with a history of international migration, enrolled in different cohorts and minors (enterprise services, language teaching and translation) at the Autonomous University of Zacatecas. The region where the study was conducted is well known for its long tradition of migration to the United States (CORNELIUS, 1981; DURAND \& MASSEY, 1992; GOLDRING, 2002). In fact, due to its characteristics, government authorities have described Zacatecas as a "binational state"(THOMPSON, 2005, p.4).

\section{CONSTRUCTING TRANSNATIONALISM THROUGH WRITING AND PERSONAL NARRATIVES}

This paper focuses merely on the discussion of a portion of the study's qualitative data gathered through semi-structured interviews. The qualitative data collection was done through the implementation of two instruments given to the group of students with history of international migration. The first instrument consisted of a short writing composition, in which participants described their schooling experiences in the U.S. and in Mexico. After completing this task, students were scheduled to participate in a semi-structured interview with the researcher revolving around the same topic. The objective of using such an approach was based on the principles of "cyclical data analysis" (MACKEY \& GASS, 2016, p.230). This procedure allowed the participants to have some background of the topics to be discussed in the interview and to explore general ideas about the experiences they shared in the interviews. It also provided the researcher with a framework for a more informed execution of the interviews.

It is worth noting here that the experiences narrated provide evidence of the conflicts and benefits inherent to the unique migration journeys and schooling experiences of the participants. However, due to the limited space, I have decided to only focus on a portion of the narratives that specifically exemplify the exchange of social and sociocultural remittances. This is in an effort to expand our knowledge on how these exchanges take place and their impact on transnational youths' sense of space, language practices and identity construction. By focusing on the exchange of social and sociocultural remittances it is not my intention in any way to disregard the 'side effects' of such exchanges or the high costs paid at many levels by those who undergo a process of (im)migration. These aspects will be considered in future stages of analysis as the research progresses; and future research in this area should explore these issues deeply. 


\section{PERSONAL NARRATIVES OF TRANSNATIONAL SPACES}

Throughout the interview exchanges, the participants provided narratives that vividly described myriad positive and negative aspects of their life and school experiences in Mexico and in the United States. Through the implementation of semi-structured interviews it was possible to incorporate elements of animating interview, which aimed at eliciting "narratives of experience" (HOLSTEIN \& GUBRIUM, 2011, pp.156-157). These narratives provided sequential accounts of the events as experienced by the participants, therefore fulfilling the characteristics described in the Labovian narrative analysis model (LABOV \& WALETZKY, 1967/1997). The Labovian model allows for a basic analysis that illuminates the characteristics that constitute a narrative (ANNA DE FINA, 2003). Additionally, conducting narrative analysis has been regarded as an effective tool "for the study of a wide range of aspects relevant to the study of language in society" (A DE FINA \& GEORGAKOPOULOU, 2008, p.380) and to locate and dissect "how the structure of the story reflects social actions"(ÖZYILDIRIM, 2009, p.1220). This particular feature was fundamental in order to find evidence of social and sociocultural remittances in the narratives gathered, and analyzed in this article, which supports the choice of the Labovian model.

According to Patterson (2012, p.33) there are four main advantages when working with this model: 1 ) the practicality of locating "important narratives within the transcript" by following the model's criteria, 2) the individual structures of narratives are revealed and admit comparison, 3) by analyzing linguistic aspects "that encode various types of evaluation" the narrator's perspective can be assessed, 4) the approach is flexible to particular types of studies and data. Given its advantages and features Labov and Waletzky's model has proven to be useful in the analysis of data from previous research on immigrant identity (DE FINA, 2003), and research investigating highschool students' narratives of exclusion and construction of self (LÓPEZ-BONILLA, 2004).

\section{TRANSNATIONAL YOUTH IN CENTRAL-NORTH MEXICO}

The participants in this study were recruited at the Autonomous University of Zacatecas ${ }^{2}$, and they were assigned pseudonyms to protect their identity. The qualitative data for this article was obtained from a corpus of fifteen interviews with

2. The name of the institution was translated from the original Spanish: Universidad Autónoma de Zacatecas. 
students between nineteen and twenty-five years old, all of them with a history of international migration between Mexico and the U.S. The stories, experiences and circumstances of each individual are unique considering the particularities of their individual migration journey (HAMANN ET AL, 2008). However, they share some common features including: 1) having command of Spanish and English, 2) having experienced a process of return migration and/or relocation in Mexico, and 3) having consistent engagement in transnational practices involving Mexico and the U.S. The participants provided insightful qualitative data through semistructured interviews and writing compositions. For the purposes of this paper, only excerpts from two interviews will be shown and discussed.

\section{FROM SEMI-STRUCTURED INTERVIEWS TO PERSONAL NARRATIVES}

This section focuses on the discussion of sample narratives taken from the interview corpus of the study currently in progress. The excerpts presented correspond to two female participants, and they were chosen on the basis of their content of remarkable examples of social and sociocultural remittances. Considering that language is a fundamental element of identity (BUCHOLTZ \& HALL, 2010; KROSKRITY, 2000), participants were given the choice to have the interview in English or in Spanish and they were welcome to use their linguistic repertoires creatively at any point of the interview in order to make them feel comfortable and to capture their linguistic practices throughout the exchange. The narratives presented in this section are complete in the sense that they align to Labov and Waletzki's six features needed to identify a narrative. Based on Patterson (2012, pp. 30-33) the features of the analysis can be explained as follows: 1) Abstract, which is a summary of the story, 2) Orientation, proving general details to understand the content of the story and how it happens, 3) Complicating action, comprising the sequence of events making up the story, 4) Evaluation, which is the central part of the story that indicates the "narrator's perspective", 5) Result, indicating the ending of the story, 6) Coda, a discretionary element by means of which the narrator connects the story to present at the time that end of the narrative is indicated. The analysis led to locating findings at two levels. The first level offers evidence of the role that social remittances played in the emergence of transnationalism in the lives of two participants who were born on opposite sides of the border. The second level looks at the role of sociocultural remittances, and their impact on the participants' identity construction, interactions with family members, language learning and language use. The findings will be discussed in more detail in the following sections. 


\section{SOCIAL REMITTANCES AND BECOMING TRANSNATIONAL 'HERE' AND 'THERE'}

Transnationalism starts with border crossing. It is according to Castles et al. (2014) the phenomenon resulting from interactions "over long distances"(p.41), where migrants perforate virtual and physical borders derived from the mobility generated by globalization. In the words of Levitt and Waters (2002), transnationalism refers to the constant movement of people across "communities of origin and destination"(p.5). As a child located in Mexico, Adriana did not physically cross the border to go to the U.S., but she became transnational due to the exchange of social and sociocultural remittances that were transmitted transversally, that is at the points of encounter of the generations, within her family. When asked to tell her story, Adriana talked about ber, but her story was interestingly framed within the story of her mom and her family. Therefore, her narrative illuminates her identity at an individual level and also as part of a community (her family). Adriana's narrative describes a series of events that happened before she was even born, the practices and ideologies she describes are seen in the analysis as social remittances marking the emergence of transnationalism in her life:

"It became a part of the family"

\begin{tabular}{|c|c|}
\hline & English (original) \\
\hline $01 \mathrm{~A}:$ & OK. Well, I'm from Jerez, Zacatecas. \\
\hline 02 & I have lived there all my life. \\
\hline 03 & However, my mom, uh, is a citizen of the United \\
\hline 04 & States. \\
\hline 05 & She wasn't born there, but she became a citizen \\
\hline 06 & because when she was, uh, very small. \\
\hline 07 & They went there and they lived for a long time over \\
\hline 08 & there, so she has (.) I think junior high', part of junior \\
\hline 09 & high she studied over there, and then she came back \\
\hline 10 & here; and that's when she got married with my dad \\
\hline 11 & and everything else, right? \\
\hline 12 & But, yeah, all of my (.) of her brothers and sisters are \\
\hline 13 & as well citizens, and (.) from, (.) uh, (.) it became like \\
\hline 14 & part of the family to continue (.) uh, making that, \\
\hline 15 & hmm (.) how to say? (.) \\
\hline 16 & Like, to continue having the rest of the family as \\
\hline 17 & citizens or residents of the United States. \\
\hline 18 & Like, it was something that it was beneficial for us so, \\
\hline 19 & that's why my sisters and I are doing the same thing, \\
\hline 20 & like we had to go and do the interviews, and \\
\hline 21 & everything because well (.) they think is good for us. \\
\hline
\end{tabular}

Figure 1. Interview excerpt edited', coded and annotated, participant: Adriana.

3.The three figures in this article present the narratives as told originally by the participants. The edition, codification and annotation consisted in locating Labov \& Waletzki's six clauses for analysis, and inserting transcript conventions according to Anna De Fina and Georgakopoulou (2015): (.) Noticeable pause, and @ Laughter (the number of @ indicates the approximate duration). 
When asked the language she preferred to have the interview in, Adriana states she feels comfortable in both. She spoke English confidently and made creative and flexible use of Spanish throughout the whole interview. Adriana starts to tell her story by locating herself geographically and she is careful to emphasize her tie with Mexico by saying she has lived in a place known as being a traditionally migrant town in Zacatecas (Mexico) all ber life (lines 1-2). In contrast, Adriana immediately identifies her mom as a citizen of the United States. Even though Adriana's mom was not born in the U.S. she became a citizen because as a child, she was taken there and she spent a long time in the U.S. (line 7). Although, she indicates a slight doubt by saying I think (line 8), Adriana knows that her mom accessed basic education in the U.S., which implies that Adriana's mom was mainly socialized in the U.S. having spent her childhood and teen years there. The complicating action located in lines 03-12 of this narrative provides details on the migration practices that Adriana's mom and her family have performed since before Adriana was born. These practices include a process of return migration, which is visibly motivated by or at least involving Adriana's mom marriage (lines 9-10). This event significantly marks the beginning of Adriana's life and story when she uses the expression and everything else (line 11) to indicate what came after her parents' marriage. By using the tag question right? Adriana seems to include the interviewer in the story assuming that both the interviewer and her share a cultural background of the rite of marriage and its purpose of building a family.

As Adriana continues telling the story, she provides information of what can be identified in Levitt's (1998) terms as the emergence of a system of practice. Lines 12-17 describe the migration history of the family. In her narrative, Adriana describes how all her mom's bothers and sisters engaged equally in the practice of migrating to the U.S. By involving the whole family, this practice became some sort of ritual, heritage or tradition for them, seemingly rooted on the one hand in the family's belief that migration has an elevated value that should be sought and preserved (line 18); and on the other hand promoted by what Durand (2007) calls the "reproduction of the migration circuit", a practice embedded in the global exchange of remittances used to "maintain the functioning of the circuit" (p.226). In addition to the previous, this tradition was also legitimized by the institutional pattern the family followed in order to continue baving the rest of the family as citizens or residents of the United States (lines 16-17). By gaining citizenship, the members of Adriana's family engaged in civil participation (BORUCHOFF, 2010), which was transmitted transversally to the whole family until it also reached Adriana and her sisters (line 19). In addition to the previous, Levitt's (1998) third type of social 
remittances: social capital, is found in the fact that by having a resolved migratory status in the U.S. Adriana's family enjoys a prestige on both sides of the border that contrasts with the wide spread image of the undocumented migrant. Therefore, Adriana and her family members developed an individual and collective identity linked to the family's migration practices and the institutionalized pattern to residency or citizenship in the U.S. Finally, the last part of Adriana's narrative shows further evidence of a normative structure when she explains that her individual engagement in migration practices, was regarded by the family (embodied in the use of the pronoun they, line 21) as being beneficial for her and her sisters. The approach taken by Adriana's family can be regarded as further evidence of the emergence of transnationalism as later in the interview she vividly describes episodes of her life, activities and practices that flow between Mexico and the U.S. reflecting what Boruchoff (2010) identifies as a "transnational perspective" that conceives the development of "the world in which migrants live" as inclusive of "two national territories"(p.70).

The narrative of a second participant named Becky describes how she became transnational there, on the other side of the border. Upon the start of the interview she said she might answer in English and in Spanish because she struggles to express some things in English and some things in Spanish. The excerpt below shows her original answer in Spanish and my translation of it into English. Her story captures the influence of her father's beliefs, which represent normative structures, as the basis for the emergence of transnationalism: 
"More of the values from Mexico"

\begin{tabular}{|c|c|c|}
\hline & Spanish (original) & English (translation) \\
\hline 01 B: & OK. Bueno, pues yo nací en Los Ángeles, & OK. Well, I was born in Los Angeles, \\
\hline & California. & California. \\
\hline 03 & Estuve viviendo por siete años más o & I lived there for seven years more or \\
\hline 04 & menos y nos venimos aquí a México & less and we came here to Mexico \\
\hline 05 & como en el 2000, y pues empezamos aquí & around 2000 , and well, we started to make \\
\hline 06 & a hacer nuestra vida. & our life here. \\
\hline 07 & Mi papá decidió venirse para acá porque & My dad decided to come here because \\
\hline 08 & quería que tomáramos los valores más de & he wanted us to have more of the values \\
\hline 09 & México que de allá, por eso nos & from Mexico than from over there, that's \\
\hline 10 & regresamos para acá. & why we came here. \\
\hline 11 & Él tenía aquí a su familia, sus papás, & He had his family here, his parents, \\
\hline 12 & entonces pues aquí empezamos a (.) Aquí & so here we started to (.) Here \\
\hline 13 & entré a la escuela a primero, allá & I started first grade, over there \\
\hline 14 & solamente hice el kínder. Pues en realidad & I only did kinder garden. Well, that was \\
\hline 15 & fue eso, que él quiso venirse por eso. & it, he wanted to come back for that reason. \\
\hline 16 & Nos dice que él no se arrepiente de & He tells us he doesn't regret \\
\hline 17 & habernos traído por ese aspecto de que & bringing us here on that aspect \\
\hline 18 & tomamos valores culturales de cómo es & of us taking cultural values of how it is \\
\hline 19 & aquí en México, más que (.) En Estados & here in Mexico, more than (.) In the United \\
\hline 20 & Unidos es un poco más materialista para & States it is a bit more superficial for \\
\hline 21 & nosotros, entonces por eso decidió que & us, so that's why he decided that \\
\hline 22 & nos viniéramos para acá. & we came here. \\
\hline
\end{tabular}

Figure 2. Interview excerpt edited, coded and annotated, participant: Becky

Similarly to Adriana, Becky's story begins with an orientation clause where she provides information on her place of birth: Los Angeles, California (lines 1-2), and immediately after that, she provides a short summary of her and her family's migration journey by describing what happened (lines 03-06). Although she shows doubt, Becky provides an approximation of the number of years she lived in the U.S., 7 years, (line 3 ) and the date of her family's return to Mexico around 2000 (line 5). It is noticeable that she switches from the first person I: I lived there (line 3), to the second person plural we: we came bere (line 4), and we started to make our life bere (lines 5-6), indicating a sense of collectiveness and family support in the process of return and also capturing the essence of the reason for that return. Additionally, Becky uses the binary there - bere in both phrases referring to the U.S. and Mexico respectively, this feature is consistent throughout her narrative.

Becky's story develops and presents a complicating action that provides details on the family's process of return to Mexico. In line 07, Becky's father is presented as the agent of change: My dad decided to come bere, immediately followed by the reason for returning: because be wanted us to bave more of the values of Mexico than from over there. The reason offered by Becky's father as the main motivation to return 
explicitly states a normative structure represented in what her father identified as the values of Mexico, a type of remittance that appears to have been heavily transmitted to Becky and her family, as it is constantly presented and reinforced throughout the narrative of the entire interview. This idea of the values of Mexico emerging from Becky's narrative evokes Petrón's (2008) conceptualization of "valores del rancho (rural values)", which according to the data in her study includes "the importance of hard work, the value of money in the long term, and commitment to family"(p.106). In fact, Becky confirms the family tie that his father had in Mexico: He bad bis family bere, bis parents (line 11), and once again she emphasizes: be wanted to come back for that reason (line 15). This explanation implies the existence of the strong family ties of Becky's father and therefore the high value that he puts on family, which is reinforced by the fact that he eventually returns with his own family on the basis of the affective investment he made on both sides of the border. On the one hand, from north to south the commitment and connection to his parents, and on the other hand, in the U.S. the constant positive emphasis on family values as a normative structure among his children. In addition to the affective investment, later excerpts of Becky's interview describing the family house provide evidence of the economic investment made by his father to maintain the household in their hometown in Mexico, which coincides with Durand's (2007) description of how migrants and their families benefit from what he identified as remittances type investment which are destined to the acquisition of "long-term goods and services"(p.222).

Finally, the last part of Becky's narrative marked by a coda provides information at two levels, first, it shows her father's reinforcement of what Becky calls cultural values (line 18) by stating that be doesn't regret (line16) his decision. Second, Becky finally defines what her father meant by cultural values as in lines 19-21 when she explains that in the United States it is a bit more superficial for us. Similarly to Petrón's (2008) findings, this phrase also captures the perceived differences of the value of money on each side of the border, Becky's use of the pronoun us captures once again the collective character of her story and is left open to be interpreted in terms of a community integrated by her and her siblings or when put against the wording In the United States the pronoun us could be understood as referring to Mexicans given her previous references to bere in Mexico (lines 04, 09 and 19).

\section{SOCIOCULTURAL REMITTANCES, IDENTITY AND LANGUAGE PRACTICES}

A series of transformations take place within the social fields where migrants and non-migrants coexist as the flow and exchange of social and sociocultural 
remittances becomes dynamic (MARTÍNEZ GÓMEZ \& TLELO TEPOX, 2017). Particular aspects of people's identities are challenged, influenced and inevitably shaped by the narratives, beliefs and practices, which materialize in the form of objects and goods exchanged in the context of transnationalism. Through the exchange of these symbolic goods migrants on both sides of the border receive and internalize the messages and beliefs embedded in them (RIVERA-SÁNCHEZ, 2004). Adriana's narrative demonstrates the role that sociocultural remittances had in her life, particularly in her language learning process:

"Well, we brought you these movies from the United States. They're in English!"

\begin{tabular}{|lll|}
\hline & English (original) \\
01 & A: & Hum (.) well, we have shared our experiences a lot and they (.) \\
02 & Well, it's different because (.) hum (.) some of them said \\
03 & that (.) they feel like they belong more here than there, and \\
04 & that they, well, they have the experiences where they, well, \\
05 & of course: "My mom and dad speak to me in Spanish", but in \\
06 & school it was English", and that's when everything comes in \\
07 & with bilingual things (.) and they come here and everything \\
08 & is in Spanish and they start getting confused because they \\
09 & were used to seeing all the topics in English, and well, I \\
10 & grew up with just Spanish, but English was something that \\
11 & it was always present, like I didn't (.) My mom wasn't like \\
12 & teach me, teaching me or anything, but it was just like: \\
13 & "Well, we brought you these movies from the United States. \\
14 & They're in English!"', And I was like: "OK, I don't \\
15 & understand anything" but I was obsessed with the movies \\
16 & and I wanted to keep seeing them, and it was the same with \\
17 & video games and other things, and we share that experience \\
18 & like how the contrast is (.) some of them have, had even \\
19 & asked me where did I learned English or if I actually lived in \\
20 & the United States, and I'm like: "No, I have never lived \\
21 & there" (.) And they're like "Why?" or uh, "you sound kind \\
22 & of like a native speaker", and I'm like "No, I just (.) I learned \\
23 & here (.)" actually more on my own than @ @ in classes or \\
24 & anything (.) And well, we (.) share a lot, and it's good because \\
25 & well, (.) some identify with each other and at the same time we \\
26 & see like both sizes (.) both sides! Sorry, I said sizes! @@ And \\
27 & that's good, I think that's really good, we're like a huge family \\
28 & over here right now @ @. @. \\
\hline
\end{tabular}

Figure 3. Interview excerpt edited, coded and annotated, participant: Adriana

This narrative derived from Adriana's response when asked about her relationship with other students in the B.A. program who have lived in the U.S. Adriana indicates that there has been an active exchange of personal experiences (line 01 ). She elaborates by providing an example on their discussions about belonging (line 03), and the language practices of some of them at home and in the school (lines 05-06). She offers her perspective on the struggles of her classmates regarding the use of Spanish at school in Mexico after having used mainly English within the academic context in the U.S. (lines 08-09). Adriana uses the context 
of her classmates' experiences to frame her own experience speaking and using Spanish and English. In line 10 Adriana goes on to say she grew up with just Spanish, but she immediately explains how English was always present (line 11). What is most remarkable in this narrative is the reason why English was always present. It was precisely a consequence of the dynamic exchange of social remittances around her, but it was particularly through sociocultural remittances that she engaged in the process of language learning. In line 11 Adriana clarifies that her mom did not teach her English; the language was rather introduced in this case through movies acting as symbolic goods as shown in the quote "Well, we brought you these movies from the United States, they're in English!" (lines 13-14) and also through video games and other things (line 17).

As Boruchoff (1999) explains, the objects carried by (im)migrants across borders "acquire myriad meanings for different individuals or for an individual at different points in their life"(p.502). On a first level these movies were chosen by Adriana's family as a gift or souvenir that was especially and carefully chosen for her, despite the fact that they were in English. This interpretation resembles Boruchoff's concept of "recuerdos"(p.503), although it differs from her definition of them as objects that are mainly exchanged to mark an important social event in people's lives. In this case the movies brought to Adriana are more of a recuerdo in the sense of a trip souvenir that reassures her of the family's affection acquiring therefore a symbolic value and acting as what Durand (2007) calls complementary remittances, type in-kind (p.224). Durand explains how objects such as: toys, decorations, gifts, among other objects that are normally "difficult to find in the country of origin" (p.224) are highly appreciated and welcome by families. On a second level the movies can be interpreted as the embodiment of a normative structure in Levitt's (1998) terms that aimed at promoting the learning and use of English. Given the migration tradition of Adriana's family, learning English at an early age through the use of these souvenirs coming from the U.S. can be regarded as an act of reinforcement of the values attached to the transnational character of the family.

As Adriana's narrative continues, she describes an important dimension of her language learning process. Adriana begins to bring the story to the present as she provides an account of her experience of learning the language through movies and videogames brought from the U.S. In an unexpected turn of the story, she explains how her classmates who have lived in the U.S., ask about her English language instruction (line 19) as to them she sounds kind of like a native speaker, to which she proudly replies "No, I've never lived there", "No, I just learned bere" (lines 20-23). 
These phrases imply a sense of attachment to Mexico based on Adriana's use of the binary 'there' and 'here', particularly in the case of the first phrase I've never lived there.

The end of the narrative is marked by a coda, where Adriana summarizes the story. She elaborates and confirms how as a group, her and other students share a lot (line 24), and through this sharing they identify with each other (line 25) and are able to contrast their experiences (line 26). This two-level 'identification' and 'contrast' performed by students in Adriana's description could be regarded through the lens of Du Bois' (2015) notion of "double-consciousness" (p.5). In this sense, the 'identification' and 'contrast' could have a particular value or significance to the eyes of Adriana as she conceives herself and as she tries to negotiate the way in which 'the others' perceive her. This negotiation and 'level' of consciousness could also become more complex, as according to Flores and Jiménez Román (2009) more layers of identity can be added to the equation resulting in what they termed "triple-consciousness" in the particular case of their research with afro-latinos in the U.S. The potential layers applicable to Adriana and her classmates would have to be subject to further study and reflection in future research.

In the last bit of the account, Adriana includes herself as part of the group of students referred to in the question that triggered the narrative by saying we're, which is then followed by: like a buge family over bere right now (lines 27-28). In this phrase, Adriana seems to confirm her identity anchored to the group of students she now identifies as her family in the school context. Her words can be interpreted in two ways: 1) on her end, there is a distance clearly marked by the statements she made in lines 20-23 emphasizing that she did not have the same upbringing as her classmates in the U.S., and 2) on her classmates' end, it is marked by the identification of Adriana in terms of her linguistic command as kind of like a native speaker. It is remarkable that she uses the metaphor family to describe the atmosphere inside the school context. The use of this metaphor coincides with the discussion of the previous section about the value of family in Mexico, place that is evoked by Adriana's use of the phrase over bere right now (line 28). Through the use of this element, Adriana locates and brings the narrative and events back to the present.

\section{CONCLUSION}

This paper has provided an overview of the concepts social and sociocultural remittances by bringing together typologies proposed by the Mexican and U.S. schools of thought in an effort to amplify the understanding of the concepts emanating from scholarly research conducted in different contexts. Considering 
that the narratives of the participants are framed in the context of intense transnationalism resulting from the historic and prevalent migration flow between Mexico and the U.S. questions on the potential transnational practices emerging in other contexts where migration flows follow different patterns are raised. Although this paper presented only a few examples of the narratives of this group of transnational youths pursuing tertiary education in Mexico, it aimed at illuminating the significant role that social and sociocultural remittances have in some aspects of the identity construction of transnational youths. By analyzing participants' narratives through the Labovian model in combination with the remittance-typologies consulted and used throughout the analysis, this paper was able to provide evidence of the emergence of transnationalism in the lives of youths marked by a family (im)migration journey or tradition on both sides of the MexicoU.S. border.

Moreover, the narratives provided insights to understand how a portion of the language practices of these youths is influenced by the exchange of sociocultural remittances in particular, and the impact of this on perceptions that individuals and groups have about each other's identities. Exploring the fascinating world of social remittances and the symbolic objects that cross borders represents a fertile ground to better understand how identities are negotiated at individual and collective levels. Thus, the exchange of discourses, ideologies and goods particularly in today's world powered by technological progress is rapidly leading to fragmentations, but also to the reconfiguration of people's identities and sense of global citizenship as fluid constructs.

\section{REFERENCES}

APPADURAI, A. (1996). Modernity at Large. Minneapolis, MN: University of Minnesota Press.

AVILÉS, A. G., \& MORA PABLO, I. (2014). Niños migrantes de retorno en el centro de México: explorando su identidad. Revista de Investigación Silogismo, 1(14), 10-21.

BORJIAN, A., MUÑOZ DE COTE, L. M., VAN DIJK, S., \& HOUDE, P. (2016). Transnational Children in Mexico: Context of Migration and Adaptation. Diaspora, Indigenous, and Minority Education, 10(1), 42-54.

BORUCHOFF, J. (1999). Equipaje cultural: objetos, identidad y transnacionalismo en Guerrero y Chicago. In G. Mummert (Ed.), Fronteras Fragmentadas (pp. 499-518). Mexico: Colmich. 
BORUCHOFF, J. (2010). Transnational perspectives on migrant civic and political engagement. Retrieved from Washington, D.C.: https://www.wilsoncenter.org/sites/default/files/ Chicago Eng.pdf - page $=68$

BUCHOLTZ, M., \& HALL, K. (2010). Locating identity in language. In C. Llamas \& D. Watt (Eds.), Language and Identities (pp. 18-28). Edinburgh, SC: Edinburgh University Press.

CASTLES, S., DE HAAS, H., \& MILLER, M. J. (2014). The Age of Migration: International Population Movements in the Modern World (Fifth ed.). Houndmills: Palgrave MacMillan.

CHRISTIANSEN, M. S., TREJO GUZMÁN, N. P., \& MORA-PABLO, I. (2018). "You know English, so why don't you teach?" Language ideologies and returnees becoming English teachers in Mexico. International Multilingual Research Journal, 12(2), 80-95.

CORNELIUS, W. A. (1981). Mexican migration to the United States. Proceedings of the Academy of Political Science, 34(1), 67-77.

DE FINA, A. (2003). Identity in narrative: A study of immigrant discourse. Amsterdam, NL: John Benjamins Publishing.

DE FINA, A., \& GEORGAKOPOULOU, A. (2008). Analysing narratives as practices. Qualitative Research, 8(3), 379-387.

DE FINA, A., \& GEORGAKOPOULOU, A. (2015). The bandbook of narrative analysis. Chichester, WS: John Wiley \& Sons.

DU BOIS, W. E. B. (2015). The Souls of Black Folk. New Haven: Yale University Press.

DURAND, J. (2007). Remesas y desarollo. Las dos caras de la moneda. In P. Leite, S. Zamora, \& L. Acevedo (Eds.), Migración internacional y desarrollo en América Latina y el Caribe (pp. 221-236). Mexico: Conapo.

DURAND, J., \& MASSEY, D. S. (1992). Mexican migration to the United States: A critical review. Latin American Research Review, 27(2), 3-42.

FLORES, J., \& JIMÉNEZ ROMÁN, M. (2009). Triple-consciousness? Approaches to Afro-Latino cultre in the United States. Latin American and Caribbean Etbnic Studies, 4 (3), 319-328.

FOURON, G. E., \& GLICK SCHILLER, N. (2002). The generation of identity: Redefining the second generation within a transnational social field. In P. Levitt \& M. C. Waters (Eds.), The changing face of home: The transnational lives of the second generation (pp. 168-208). New York, NY: Russell Saga Foundation. 
GOLDRING, L. (2002). The Mexican State and Transmigrant Organizations: Negotiating the Boundaries of Membership and Participation. Latin American Research Studies Association, 37(3), 55-99.

HAMANN, E., \& ZÚÑNIGA, V. (2011). Schooling and the everyday ruptures transnational children encounter in the United States and Mexico. In C. Coe, R. R. Reynolds, D. A. Boehm, J. M. Hess, \& H. Rae-Espinoza (Eds.), Everyday Ruptures: Children, Youth, and Migration in Global Perspective (pp. 141-160). Nashville, TN: Vanderbilt University Press.

HAMANN, E., \& ZÚÑNGA, V. (2011). Schooling, national affinity(ies), and transnational students in Mexico Faculty Publications: Department of Teaching, Learning and Teacher Education (pp. 57-72). Nebraska.

HAMANN, E. T., ZÚÑIGA, V., \& SÁNCHEZ GARCÍA, J. (2008). From Nuevo León to the USA and back again: Transnational students in Mexico. Journal of Immigrant \& Refugee Studies, 6(1), 60-84.

HOLSTEIN, J. A., \& GUBRIUM, J. F. (2011). Animating interview narratives In D. Silverman (Ed.), Qualitative research: Issues of theory, method and practice (pp. 149-167). London: Sage Publishers.

KROSKRITY, P. V. (2000). Identity. Journal of Linguistic Antbropology, 9(1-2), 111-114.

LABOV, W., \& WALETZKY, J. (1967/1997). Narrative analysis: Oral versions of personal experience. In J. Helm (Ed.), Essays on the verbal and visual arts (pp. 12-44): Seattle/ London: University of Washington Press.

LEVITT, P. (1998). Social remittances: Migration driven, local-level forms of cultural diffusion. The International Migration Review, 32 (4), 926-948.

LEVITT, P., \& GLICK-SCHILLER, N. (2004). Conceptualizing simultaneity: A transnational social field perspective on society. The International Migration Review, 38(3), 1002-1039.

LEVITT, P., \& LAMBA-NIEVES, D. (2011). Social remittances revisited. Journal of Ethnic and Migration Studies, 37(1), 1-22.

LEVITT, P., \& WATERS, M. C. (2002). The changing face of bome: The transnational lives of the second generation. New York, NY: Russell Sage Foundation.

LÓPEZ-BONILLA, G. (2011). Narratives of exclusion and the construction of the self. In R. Rodgers (Ed.), An introduction to critical discourse analysis in education (pp. 46-67). New York, NY: Routledge. 
MACKEY, A., \& GASS, S. M. (2016). Second language research: Methodology and design. [Kindle 4]. Retrieved from amazon.com.mx

MARTÍNEZ GÓMEZ, L. J., \& TLELO TEPOX, E. (2017). Familias transnacionales y remesas socioculturales. In J. G. Rodríguez Gutiérrez, M. Moctezuma Longoria, \& O. Calderón Morillón (Eds.), Hogares y Familias Transnacionales: Un Encuentro Desde la Perspectiva Humana (pp. 323-355). México: Juan Pablos Editor.

MASSEY, D. S., ARANGO, J., HUGO, G., KOUAOUCI, A., PELlEGRINO, A., \& TAYLOR, E. (2010). Theories of international migration: a review and appraisal. In S. Vertovec (Ed.), Migration (pp. 431-466). Abingdon, Oxon: Routledge.

MOCTEZUMA LONGORIA, M. (2017). Localización, deslocalización y simultaneidad de relaciones sociales en la perspectiva transnacional. In J. G. Rodríguez Gutiérrez, M. Moctezuma Longoria, \& O. Calderón Morillón (Eds.), Hogares y familias transnacionales: Un encuentro desde la perspectiva bumana. (pp. 21-51). México: Juan Pablos Editor.

MORA PABLO, I., RIVAS RIVAS, L. A., LENGELING, M. M., \& CRAWFORD, T. (2015). Transnationals becoming English teachers in Mexico: Effects of language brokering and identity formation. GiST Education and Learning Research Journal (10), 7-28.

ÖZYILDIRIM, I. (2009). Narrative analysis: an analysis of oral and written strategies in personal experience narratives. Journal of Pragmatics, 41, 1209-1222.

PATTERSON, W. (2012). Narratives of events: Labovian narrative analysis and its limitations. In M. Andrews, C. Squire, \& M. Tamboukou (Eds.), Doing narrative research. London: Sage Publications.

PETRÓN, M. A. (2008). Negotiating borders with "valores del rancho". Latin American Perspectives, 35(1), 104-119.

PEW HISPANIC, C. (2011). The Mexican-American boom: births overtake immigration. Retrieved from http://www.pewhispanic.org/2011/07/14/the-mexican-americanboom-brbirths-overtake-immigration/

PEW RESEARCH, C. (2018). Remittance flows worldwide in 2016. Retrieved from http:// www.pewglobal.org/interactives/remittance-map/

RIVERA SÁNCHEZ, L. (2004). Transformaciones comunitarias y remesas socioculturales de los migrantes mixtecos poblanos. Red Internacional de Migración y Desarrollo(2), 62-81.

SERNA-GUTIÉRREZ, J. I., \& MORA-PABLO, I. (2017). Critical incidents of transnational student-tecahers in central Mexico. Profile: Issues in Teachers' Professional Development, 20(1), 137-150. 
SKERRETT, A. (2015). Teaching transnational youtb: Literacy and education in a changing world. New York, NY: Teachers College Press.

THOMPSON, G. (2005). Mexico's migrants profit from dollars sent home. The New York Times. Retrieved from nytimes.com website: http://query.nytimes.com/gst/fullpage. html?res=9501E0DE163DF930A15751C0A9639C8B63\&pagewanted $=$ all

UNITED NATIONS, D. O. E. A. S. A. P. D. (2017). International Migration Report 2017: HIgbligbts (ST/ESA/SER.A/404). Retrieved from http://www.un.org/en/development/desa/ population/migration/publications/migrationreport/docs/MigrationReport2017 Highlights.pdf

VERTOVEC, S. (2009). Transnationalism. Oxon/New York: Routledge.

VICKERMAN, M. (2002). Second-generation west indian transnationalism. In P. Levitt \& M. C. Waters (Eds.), The changing face of bome: The transnational lives of the second generation. (pp. 341-366). New York, NY: Russell Sage Foundation.

YMRM. (2017). Yearbook of migration and remittances Mexico 2017. Fundación BBVA Bancomer, A.C., Consejo Nacional de Población. Retrieved from https://www.bbva.com/wpcontent/uploads/2017/07/1707_AnuarioMigracionRemesas_2017.pdf.

ZÚÑIGA, V., \& HAMANN, E. T. (2009). Sojourners in Mexico with US school experience: A new taxonomy for transnational students. Comparative Education Review, 53(3), 329353.

Recebido: 23/11/2018

Aceito: $13 / 12 / 2018$

Publicado: 29/03/2019 